EESTI NSV TEADUSTE AKADEEMIA TOIMETISED 1954. III kd., nr. 1 ИЗВЕСТИЯ АКАДЕМИИ НАУК ЭСТОНСКОИ ССР 1954. ТоМ III, № 1

\title{
СОСТОЯНИЕ И ПУТИ РАЗВИТИЯ СЕЛЬСКОГО ХОЗЯЙСТВА ПРИГОРОДНОЙ ЗОНЫ ТАЛЛИНА И СЛАНЦЕВОГО БАССЕЙНА
}

\author{
н. С. Бузулуков, \\ действительный член Академии наук Эстонской ССР
}

Сентябрьский и февральско-мартовский пленумы ЦК КПСС, исходя из глубокого знания объективных экономических законов социализма, приняли развернутую и научно глубоко обоснованную систему мероприятий, осуществление которой обеспечивает крутой подъем всех отраслей сельскохозяйственного производства и особенно ег̆о ведущей отрасли зернового хозяйства. Уже в течение ближайших $2-3$ лет будет достигнуто резкое повышение обеспеченности населения продовольствием, рост экономики колхозов и высокий уровень материального благосостояния колхозников.

В нашей стране имеются неисчерпаемые природные и экономические возможности для быстрого увеличения производства зерна, продуктов животноводства, картофеля, овощей, фруктов, технических культур. Колхозный строй в состоянии с успехом использовать все эти возможности и еще раз продемонстрировать свою великую несокрушимую силу.

Колхозы Әстонской ССР, несмотря на свою молодость (большинство из них существует не более $4-5$ лет), имеют уже значительные достижения и показали свое полное превосходство перед единоличным хуторским хозяйством. Уже в 1953 году более $70 \%$ всех основных полевых работ было механизировано. Наряду с быстрым ростом общенародной социалистической собственности, обслуживающей колхозы по линии МТС и MMC, непрерывно и быстро растет колхозно-кооперативная общественная собственность. Неделимые фонды колхозов республики за последние три года увеличились на $33,5 \%$, денежные доходы - на $35,2 \%$. Все больше средств колхозы выделяют на строительство. Если в 1950 году на строительство в колхозах было израсходовано только 4,3 млн. рублей, то в 1952 году - уже 36,8 млн. рублей. С каждым годом увеличивается валовая и товарная продукция колхозов, возрастает выдача денег и продуктов на трудодни.

Однако в деятельности колхозов, совхозов и в руководстве сельским хозяйством республики имеют место те же серьезнейшие недостатки, которые вскрыты Пленумом ЦК КПСС в отношении всего сельского хозяйства. Кроме того, развитие сельского хозяйства республики тормозит тяжелое наследство периода буржуазной Эстонии (хуторская система, 
неблагоприятная с точки зрения дальнейшего развития сельскохозяйственного производства структура сельскохозяйственных угодий, низкий удельный вес пашни, большое количество заболоченных малопродуктивных лугов и пастбищ, засоренность почв камнями). Огромный ущерб сельскому хозяйству нанесла немецко-фашистская оккупация.

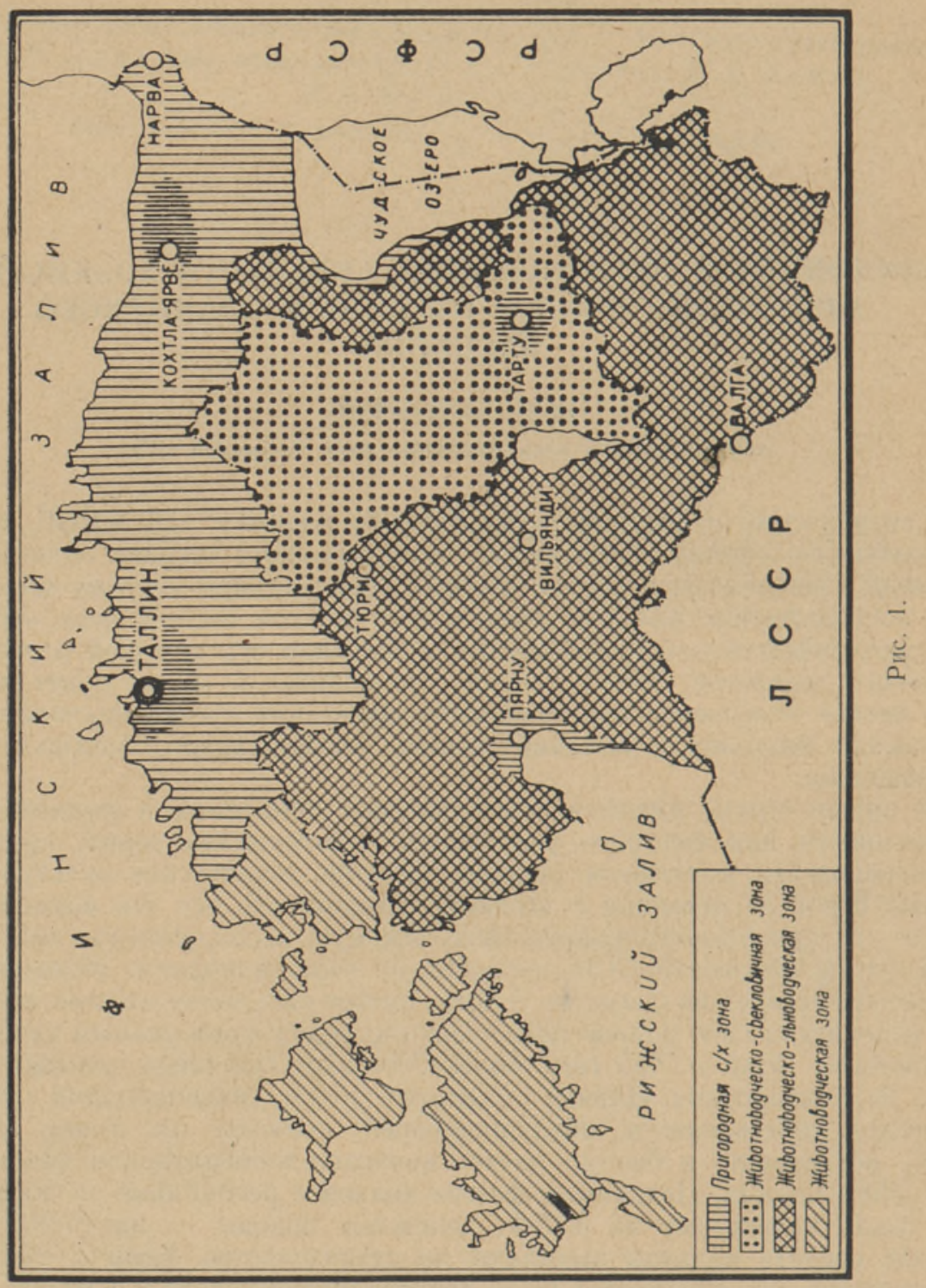

Возможности, заложенные в колхозном строе, и постоянная забота партии и правительства о Советской Әстонии создают все необходимые условия для быстрого подъема сельского хозяйства республики.

Развитие социалистического сельского хозяйства республики, как и всего Советского Союза, происходит на основе планового разделения труда в соответствии с требованиями основного экономического закона социализма и закона планомерного (пропорционального) развития на- 
родного хозяйства. В Эстонской ССР, как части Советского Союза, входящей в северо-западный экономический район, социалистическое сельское хозяйство развивается комплексно и специализируется на молочном животноводстве и свиноводстве. В сочетании с этой ведущей отраслью сельского хозяйства республики развивается производство зерна, картофеля, овощей, фруктов, кормовых и некоторых технических культур.

В соответствии с таким характером социалистического сельскохозяйственного производства республики, отвечающего как интересам специализации социалистического сельского хозяйства в целом по Союзу, так и полному удовлетворению нужд самой республики, создаются четыре производственные специализированные сельскохозяйственные зоны (рис. 1).

I. Пригородная сельскохозяйственная зона г. Таллина, Нарвы и сланцевого бассейна.

II. Животноводческо-свекловичная зона (центральные районы республики).

III. Животноводческо-льноводческая зона (юг республики).

IV. Западная животноводческая зона, охватывающая острова и западную прибрежную материковую часть республики.

Академия наук Әстонской ССР ведет комплексное изучение состояния и перспектив развития этих зон. В прошлые годы завершено изучение четвертой зоны ', где условия развития сельскохозяйственного производства наиболее неблагоприятны, и намечена соответствующая система мероприятий, принятая правительством республики. В настоящее время близится к завершению исследование первой из указанных выше зон (пригородной); ведется подготовка к изучению третьей (южной) зоны.

Работа выполняется коллективом научных работников пяти институтов Академии наук Әстонской ССР (Экономики, Растениеводства, Животноводства и ветеринарии, Мелиорации и освоения осушенных земель, Зоологии и ботаники).

Ниже кратко излагаются основные предварительные итоги изучения сельского хозяйства прнгородной зоны.

\section{Общая характеристика и пути развития сельского хозяйства пригородной зоны}

Промышленность республики в основном сосредоточена на севере (г. Таллин, сланцевый бассейн и г. Нарва). В связи с быстрым ростом промышленности растет население городов. Если в буржуазной Эстонии в городах жило 32 процента всего населения, то в настоящее время процент городского населения составляет уже 48. Важнейшая задача сельского хозяйства пригородной зоны состоит в том, чтобы обеспечить население этих промышленных центров продуктами питания, особенно свежими овощами, картофелем, ягодами, фруктами и цельным молоком.

Перспективы развития пригородной зоны намечаются исходя из научно обоснованных норм питания населения. В результате изучения состояния сельскохозяйственного производства пригородной зоны выявляются резервы, разрабатываются пути и конкретные меропряятия дальнейшего развития сельского хозяйства в свете решений сентябрьского и февральско-мартовского пленумов ЦК КПСС.

Пригородная зона г. Таллина и сланцевого бассейна охватывает почти $25 \%$ всей территории Эстонии и включает 9 административных

1 См. Э. Т. В ин т, Размещение и специализация сельскохозяйственного пронзводства в Советской Эстонии, «Известня АН ЭССР», 1952, т. І, № 1. 
районов (Харьюский, Кейлаский, Косеский, Локсаский, Раплаский, Тапаский, Раквереский, Кивиылиский, Иыхвиский). Первые шесть районов составляют пригородную зону г. Таллина, остальные - сланцевого бассейна. Эти зоны сливаются и образуют единый массив.

На территории пригородной зоны имеется 210 колхозов, 15 машиннотракторных станций (MTC), 2 машинно-мелиоративные станции (MMC) и 28 совхозов.

Земли сельскохозяйственного пользования (пашни, луга, пастбища, сады и огороды) составляют $85,3 \%$ всей территории пригородной зоны Удельный вес пашни колеблется в больших пределах: от 22,9\% в Кейласком районе до $49,6 \%$ в Тапаском районе.

Удельный вес лугов и пастбищ в зоне г. Таллина составляет $73,8 \%$, а в зоне сланцевого бассейна - 60,9\%. Продуктивность естественных лугов и пастбищ в пригородной зоне чрезвычайно низкая (3-4 ц сухого сена с га). Вопросы их коренного и поверхностного улучшения имеют важнейшее значение в деле создания прочной и устойчивой кормовой базы. К тому же значительная часть этих угодий расположена на высокопродуктивных, но запущенных, заросших кустарником, заболоченных почвах, нуждающихся в осушении.

Естественное и эффективное плодородие как лугов и пастбищ, так и пахотных почв весьма разнообразно.

В пригородной зоне преобладающими являются в основном три типа почв: 1) дерново-карбонатные, 2) дерново-глеевые и 3) болотные.

Дерново-карбонатные (рихковые) почвы занимают северную часть зоны. Удельный вес этих почв колеблется в пределах $10-25 \%$, достигая в отдельных колхозах $40 \%$ (колхоз имени Кингисеппа, Кейлаского района, и др.). Эти почвы, главным образом по мощности пахотного слоя и водным условиям, подразделяются на три группы: маломощные (38\% общего количества), среднемощные $(42 \%)$ и мощные, высокоплодородные $(20 \%)$. Таким образом, значительная часть пахотных земель относится к маломощным рихковым почвам. Так как запасы влаги в этих почвах весьма ограничены, то и экономическая эффективность их использования как пашни очень низка. На этих землях высокую экономическую эффективность дает возделывание культур, способных использовать запасы влаги более глубоких подпочвенных слоев. Такими культурами в условиях республики являются люцерна многолетнего пользова ния и эспарцет, дающие высокие и устойчивые урожаи (в среднем 50 70 щ сухого сена с га).

Второй тип почв - дерново-глеевые - занимает в среднем по зоне около $30 \%$ всей территории, а в отдельных колхозах («Тасуя», Кейлаского района, имени Кирова, Кыхвиского района, и др.) $37-47 \%$. Эти почвы обладают высоким плодородием, и при условии регулирования водного режима (осушение) они вполне пригодны для возделывания на них овощных и кормовых культур, и особенно для культурных пастбищ длительного пользования.

Третий тип - низинные болота с хорошо разложившимся торфом и богатые известью. Они составляют 10-15\% площади сельскохозяйствен ной территории и после осушения также вполне пригодны для выращивания многолетних трав, овощных и силосных культур.

Поскольку в большинстве колхозов зоны сланцевого бассейна удельный вес пашни значительно выше, чем в колхозах Таллинской зоны, в последней более остро стоит вопрос о необходимости реконструкции сельскохозяйственных угодий. В течение ближайших пятилеток удельный вес пашни в колхозах Харьюского, Кейлаского, Локсаского, Раплаского и Косеского районов следует довести до $40 \%$. 
Расширение пашни в пригородной зоне будет проведено главным образом за счет освоения заболоченных и запущенных, но высокоплодородных дерново-глеевых почв и отчасти за счет низинных болот. Введение этих земель в культуру связано с проведением мелиоративных работ значительного объема. По всей пригородной сельскохозяйственной зоне в перспективе ближайших пятилеток комплексные мелиоративные работы предстоит провести на площади, составляющей $34 \%$ всей земли сельскохозяйственного пользования, включая естественные сенокосы и пастбища. Причем две трети этих земель составляют заболоченные минеральные почвы (дерново-глеевые) и одна треть - низинные болота. Особенно большой процент избыточно увлажненных минеральных земель расположен на юго-востоке от Таллина, в западной части Кейлаского района и в Кивиылиском районе.

В ряде колхозов пригородной сельскохозяйственной зоны заболоченные дерново-глеевые почвы и низинные болота, нуждающиеся в мелиорации, составляют до $60 \%$ от всех земель (колхоз имени Қингисеппа, Кейлаского района, колхоз «Сяде», Қивиылиского района, и др.). Освоение этих земель связано с большими затратами. Общая стоимость всех мелиоративных работ в пригородной зоне колхозов составит около 500 млн. рублей. Проведение всего объема мелиоративных работ займет продолжительное время. Однако уже в течение ближайших 2-3 лет можно провести значительные работы.

В пригородной зоне, как и в республике в целом, очень остро стоит вопрос о необходимости создания прочной и устойчивой кормовой базы. Развитие кормовой базы резко отстало от развития животноводства. Это тем более чувствуется, что респуб̆лика располагает высокопородным скотом, способным давать высокие удои. Недостаток зеленых и сочных кормов является главным препятствием в увеличении удоев. Без резкого увеличения производства зеленых и сочных кормов невозможно решать поставленные перед общественным животноводством задачи. Поэтому создание кормовой базы, особенно увеличение производства зеленых и сочных кормов, имеет важнейшее значение в деле дальнейшего развития животноводства. Прочная и устойчивая кормовая база должна быть создана в каждом колхозе. Әто главная предпосылка обеспечения крутого подъема развития животноводства. При условии успешного разрешения этого вопроса можно получить удои в среднем по республике 3-4 тыс. литров в год на каждую корову. В последние годы удои по республике составили 1700 литров в среднем на 1 фуражную корову.

В колхозах зоны г. Таллина уже в настоящее время имеется больше 45 переводных голов скота на каждые 100 га пастбищ, а в районе сланцевого бассейна - свыше 60 голов; если учесть и скот колхозников в личной собственности, то в Таллинской зоне на каждые 100 га пастбищ приходится в среднем 73 головы, а в зоне сланцевого бассейна - 109. В совхозах нагрузка еще больше: в первой зоне -126 голов, во второй -134 (без учета скота рабочих).

При этом надо иметь в виду, что культурных пастбищ еще мало, а естественные пастбища очень низкой продуктивности.

Летний период в условиях республики продолжается 145-165 дней, 55-60\% удоя молока колхозы и совхозы получают за этот период. Пастбища же удовлетворяют в среднем по зоне $29-30 \%$ потребности в летних кормах, а в некоторых районах еще меньше (в Раквереском районе $-17,9 \%)$. При правильной организации хозяйства пастбища должны удовлетворять по крайней мере $60-65 \%$ потребности в летних кормах (остальные 35-40\% должны давать сеяные культуры зеленого конвейера и концентраты). Так как продуктивность естественных пастбищ 
очень низка, а культурных пастбищ еще мало, колхозы и совхозы недополучают значительное количество зеленых, притом наиболее дешевых пастбищных кормов, вследствие чего происходит большая потеря в удоях летом. Общественный скот летом приходится подкармливать многолетними полевыми травами, травами естественных сенокосов, подрывая тем самым зимнюю кормовую базу.

По 8 типичным колхозам в окрестностях Таллина в среднем на одну дойную корову дается 1992 кормовые единицы в год, в том числе за с́ет пастбищ и зеленого конвейера только 678 кормовых единиц, или-34\%. В среднем по восьми типичным колхозам сланцевого бассейна дается 2055 кормовых единиц на дойную корову, из них только 533, или $25,9 \%$, за счет пастбищ и зеленого конвейера.

Эти данные говорят о том, что все колхозы еще недостаточно обеспечивают скот кормами, и это сдерживает рост удоев. Особенно плохо скот обеспечен летом зелеными кормами за счет пастбищ и зеленого конвейера.

В качестве положительного примера можно привести совхоз «Убья», Раквереского района, который наиболее правильно организовал летнее кормление скота. В этом совхозе 53,5\% летних кормов дают естественные и культурные пастбища, 21,4\% - смесь зерновых и бобовых, 14,9\% кормовая капуста, $8 \%$ - рожь ранней весной и только $2,2 \%$ - многолетние травы. Для сравнения можно указать, что в совхозе «Кохила» многолетние травы покрывают $34,5 \%$ потребности в летних кормах, а естественные пастбища - только $11,8 \%$.

Главным звеном в деле создания кормовой базы в летний период является повышение продуктивности естественных пастбищ и особенно создание культурных пастбищ и зеленого конвейера. Естественные пастбища почти на три четверти нуждаются в улучшении, а $47 \%$ из них в Таллинской зоне и $38 \%$ в зоне сланцевого бассейна нуждаются в осушении. Культурные пастбища в Эстонии дают исключительно высокий экономический эффект. Они используются в течение $20-25$ и более лет без больших затрат труда и средств производства и дают ежегодно $2500-3000$ и более кормовых единиц с гектара. Опыт совхозов показывает, что себестоимость одной кормовой единицы трав культурных пастбищ в 7 раз ниже, чем естественных сенокосов, и в 8 раз ниже, чем зерновых культур. Культурные и естественные пастбища уже в течение бли жайших 2-3 лет должны покрыть $60-70 \%$ всей летней потребности в кормах в колхозах Таллинской зоны и $40-60 \%$ - в колхозах зоны сланцевого бассейна. Это даст возможность полностыю обеспечить зеленым кормом скот в летний период.

Очень важно иметь в виду, что значительная часть естественных пастбищ может быть превращена в культурное состояние при небольших затратах путем поверхностного улучшения. При таком освоении естественных пастбищ уже получены хорошие результаты в ряде хозяйств.

Так, в опытном хозяйстве Куузику Института растениеводства Академии наук ЭССР с естественного пастбища, урожай которого до улучшения составлял 500-700 кормовых единиц с га, после его улучшения поверхностным внесением удобрений и после организации загонной системы пастьбы скота в течение 10 лет хозяйство получает в среднем урожай в 2787 кормовых единиц с га. Для удобрения применялось в среднем в год на 1 га - 2 ц суперфосфата, $1-1,5$ ц калийного удобрения и 0,5 ц азотного удобрения. Кроме того, в период проведения опытов два раза вносилось органическое удобрение (всего 44 т на га).

В колхозе «Эдаси», Тюриского района, были заложены культурные пастбища на маломощных минеральных почвах, которые до этого давали всегя 300-400 қормовых единиц с 1 га. Способом поверхностного улуч- 
шения пастбищ на 1 га было внесено осенью 10 т навоза и весной 2 ц суперфосфата и 1 ц калийной соли. Дополнительно было подсеяно 2 кг семян клевера и 5 кг тимофеевки на 1 га. После внесения удобрений и подсева трав весной было проведено боронование травостоя. При таком способе уже в первом году было получено с га 1920 кормовых единиц, или 103 ц зеленой массы.

Такой способ улучшения пастб́ищ в пригородной зоне имеет важнейшее значение и должен широко применяться всеми колхозами и совхозами пригородной зоны.

В щелях создания прочной и устойчивой кормовой базы как в летний, так и в зимний период, кроме указанных выше мероприятий по улучшению летнего кормления скота, необходимо осуществить ряд следующих серьезных мероприятий:

1. Резко повысить урожай многолетних полевых трав.

2. Повысить урожай всех полевых культур. Важнейшее значение при этом имеет увеличение количества вносимых органических удобрений путем использования навозно-торфяных компостов, обогащенных минеральными удобрениями, и расширения посева белого донника в занятом пару, как зеленого удобрения. Опыты показывают, что белый донник дает в первом укосе $100-150$ ц зеленой массы для силоса, а запашка второго укоса равносильна внесению 25-30 тонн навоза на га. Вырашивание донника в занятом пару дает возможность покрыть $40-50 \%$ потребности в силосе и в 3-4 раза снизить затраты труда при обработке пара.

3. Обеспечить выращивание люцерны и эспарцета на маломощных рихковых почвах.

4. Производство силоса довести до 5-6 т на одну корову путем увеличения посева на силос подсолнуха, дающего в условиях республики (на торфяниках) $600-800$ ц зеленой массы с га, а также кормовой капусты и кукурузы. Необходимо, кроме того, выделять для скармливания молочному скоту не менее 20 ц картофеля в среднем на каждую дойную корову.

5. Во всех колхозах ввести зеленый конвейер с соответствующим подбором культур для обеспечения лагерно-стойлового содержания, дающего наивысший экономический эффект в условиях республики.

6. Укосы с естественных сенокосов путем поверхностного улучшения и внесения полной нормы органо-минеральных удобрений довести в ближайшие годы в среднем до 12 ц сена с га.

7. Улучшить состояние семеноводства многолетних трав, устранить практику заниженных норм высева. В ближайшие $2-3$ года довести уборочную площадь семенников лугопастбищных трав в зоне г. Таллина до 1300 га, в зоне сланцевого бассейна - до 650 га.

8. На осушенных почвах низинных болот вводить кормовые севообороты с целью выращивания на них сена, силосных культур и овощей.

Для повышения урожайности всех культур решающее значение имеет освоение правильных севооборотов. В пригородной зоне следует вводить в основном 8-9-польные полевые, 8-10-польные луговые и 7 -8-польные прифермские севообороты. Размер площади под прифермским севооборотом должен составлять $5-10 \%$ от размера пашни. В колхозах с большим удельным весом овощей следует вводить 5-7-польные специальные овощные севообороты. Введение севооборотов должно быть закончено во всех колхозах в 1955 году. В 1953 году имелись только проекты введения севооборотов для $32,4 \%$ колхозов республики.

Анализ состояния структуры растениеводства в пригородной зоне показывает, что удельный вес зерновых колеблется от 48,5\% (в колхозах Йхвиского района) до $53,1 \%$ (в колхозах Қейлаского района). В кол- 
хозах, прилегающих к г. Таллину (Харьюский район), удельный вес зерновых составляет в среднем $50,1 \%$.

Удельный вес многолетних трав колеблется в пределах от $19,4 \%$ (Харьюский район) до 22,9\% (Раплаский район). Исключение составляют колхозы Локсаского района, где удельный вес трав составляет всего $14,6 \%$, и колхозы Кейлаского района - $16,1 \%$.

Удельный вес картофеля наиболее высок в колхозах Қивиылиского $(14,1 \%)$ и Йхвиского $(13,7 \%)$ районов; в колхозах Харьюского, Кейлаского и Раквереского районов он составляет $11,2-11,8 \%$. Наименьший удельный вес картофеля в колхозах Раплаского района $(8,6 \%)$.

Наибольший удельный вес овощей в Харьюском районе $(2,3 \%)$, в колхозах, расположенных вблизи г. Нарвы $(2,4 \%)$, в колхозах Иыхвиского $(1,8 \%)$ и Кивиылиского $(1,7 \%)$ районов, а наименьший - в колхозах Раплаского района $(0,6 \%)$. Удельный вес кормовых корнеплодов, силосных культур и однолетних трав наивысший в колхозах Локсаского $(11,6 \%)$, Косеского $(10,9 \%)$ и Харьюского $(9,3 \%)$ районов.

Из прнведенных данных вндно, что в колхозах зоны сравнительно высок удельный вес многолетних трав, картофеля и овощей. Таким образом, характер специализации пригородной сельскохозяйственной зоны уже ярко проявляется в структуре посевных площадей.

Колхозы, прилегающие к промышленным центрам, имеют значительный удельный вес овощей и картофеля. Главная задача теперь состоит уже не в увеличении посевных площадей этих и других культур, а в повышении урожайности.

Урожайность всех культур еще низка. Главным образом вследствие низкой урожайности полевых культур и создаются серьезные трудности в обеспечении населения овощами, картофелем, а животноводства сочными кормами.

Площадь, занимаемая овощами в пригородной сельскохозяйственной зоне, за последние годы значительно увеличилась, возрос и удельный вес пригородной зоны в пронзводстве овощей.

Так, в 1954 году (по плану) по сравнению с 1951 годом площади, занимаемые овощами, увеличиваются в Таллинской зоне на $59 \%$, а в зоне сланцевого бассейна почти удваиваю́тся. В пригородной сельскохозяйственной зоне в 1954 году будет сосредоточено $44,7 \%$ посева всех овощей колхозов республики.

До 1954 года посевы товарных овощей были чрезмерно распылены по колхозам, и это приводило к низким урожаям вследствие плохой обработки почвы и плохого ухода за ними. Размеры посева овощей свыше 20 га в 1952 году были только в девяти колхозах зоны, а 69,5\% колхозов имели овощей каждый менее 10 га, Урожаи овощей на малых площадях (до 10 га) были в два раза ниже, а затраты труда на 1 ц намного выше, чем на крупных массивах (свыше 20 га). Так, в колхозе имени Мичурина (имеющем свыше 40 га овощей) затраты труда на 1 ц овощей составляли 0,78 трудодня, в колхозе «Койт» - 1,48, а в колхозе «Ныукогуде Пыллумеэс» - 6,8 трудодня.

Денежные доходы на 1 га овощей в колхозе жКойт» -23 тыс. руб., им. Мичурина - 17,9 тыс. руб., а в колхозе «Ныукогуде Пыллумеэс» меньше одной тысячи рублей. Денежные доходы в колхозах, имеющих овощей до 5 га, составили в среднем 6102 руб. с га, а в колхозах, имеющих свыше 20 га - 15276 руб. с га, т. е. в 2,5 раза выше.

В 1954 году производство товарных овощей в крупных размерах будет сосредоточено в немногих колхозах. Правда, пойменных площадей, где 
Урожайность овощей

c $2 a(g 0102 a=100)$

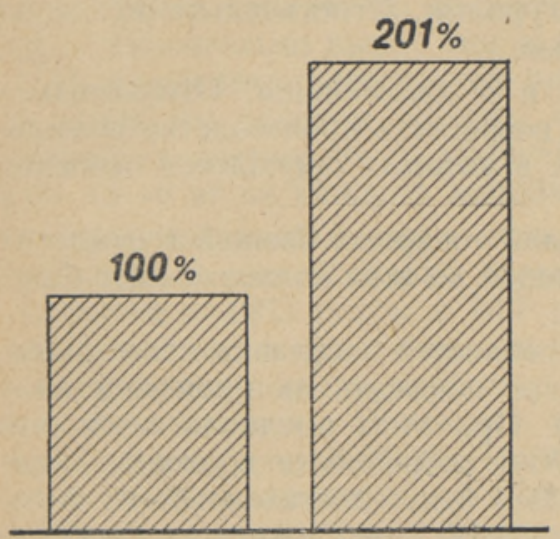

go $102 a$
Забисимосто себестоимости овощей от уровня урожсайности (6 cobxosax)

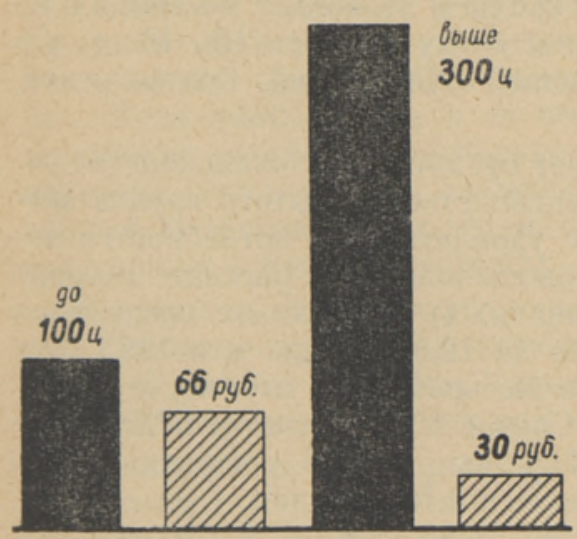

урожсай $c$ га $\boldsymbol{B}_{\text {u }}$
Денежние gохоgо от овощей на $2 a$ (go $102 a=100$ )

$341 \%$

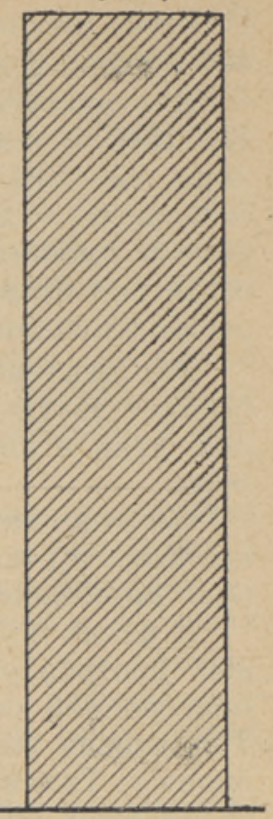

go 10 2a

bolwe 20 ia

Забисимость себестоимости картоселя от уровня урожсайности (b совхозах)

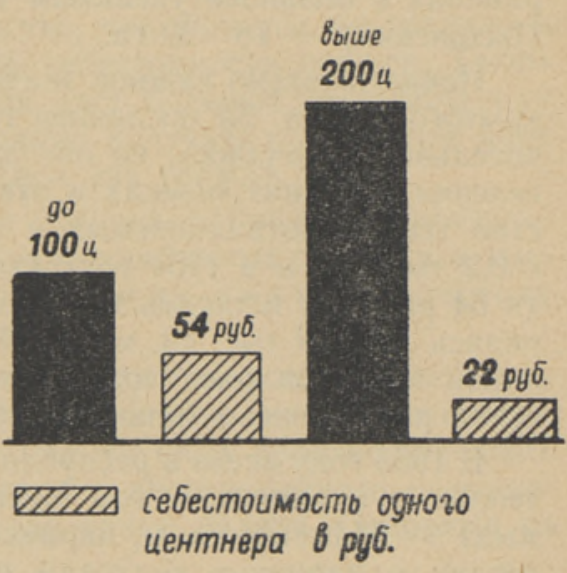

Рис. 2. Влияние размеров посевных площадей овощей на урожайность и денежные доходы от овощеводства. Зависимость себестоимости овощей н картофеля от урожайности. 
достигается особенно большая концентрация овощей, в республике мало. Поэтому овощи размещаются в основном на осваиваемых дерново-глеевых почвах и на освоенных массивах низинных болот.

В структуре овощей пригородной зоны 35-40\% занимает капуста, $12-15 \%$ - морковь, $7-10 \%$ - лук, $5-8 \%$ - огурцы, $4-7 \%$ - помидоры, $15-20 \%$ (в зоне сланцевого бассейна до 25\%) - столовая свекла, остальное - другие овощи. За последние годы в несколько раз увеличились площади, занимаемые помидорами, значительно возросли площади под столовой свеклой, луком и огурцами. Относительно медленно росли площади под капустой и морковью.

Эта тенденция будет продолжаться и в дальнейшем. Относительно быстрее других овощных культур будет возрастать производство помидоров, лука и ранних огурцов, недостаток в которых ощущается особенно остро.

Сосредоточение значительных площадей товарных овощей в немногих колхозах и резкий рост урожайности овощей во всех колхозах даст большой экономический эффект.

В целях полного удовлетворения потребностей населения промышленных центров в овощах, необходимо резко повысить их производство в пригородной сельскохозяйственной зоне. При этом предполагается, что Таллинская зона будет удовлетворять $70 \%$ потребности в овощах населения г. Таллина, а остальные $30 \%$ овощей будут доставляться из более отдаленных колхозов республики, тогда как в зоне сланцевого бассейна пригородная зона может полностью удовлетворять потребность населения в овощах. В соответствии с этим производство овощей открытого грунта в пригородной зоне должно увеличиться примерно в $2-2,5$ раза. При урожаях, предусмотренных решениями сентябрьского Пленума ЦК КПСС, необходимо, чтобы под овощи открытого грунта в колхозах пригородной зоны было отведено около $2 \%$ пашни.

В настоящее время (1954 г.) удельный вес овощей в Таллинской зоне и зоне сланцеєого бассейна - 1,5\%. По сравнению с 1954 годом площади под овощами должны возрасти к 1957 году примерно на 20$30 \%$, а урожайность - в $1,5-2$ раза. В среднем на колхоз посевная площадь овощей открытого грунта составит к этому времени 15-16 га, а в районах с большим удельным весом овощей (Харьюский, Қивиылиский, Йхвиский) - 18-20 га.

Исключительно важное значение имеет организация овощеводства закрытого грунта. За последние годы овощеводство закрытого грунта значительно увеличилось, но оно далеко не удовлетворяет потребностей населения в ранних овощах и открытого овощеводства в рассаде. Количество теплиц (отапливаемых и неотапливаемых) в колхозах республики с 0,2 тыс. кв. м в 1951 году увеличилось до 12,8 тыс. кв. м в 1953 году (в 64 раза), а площадь парников за это же время с 6 тыс. кв. м увеличилась до 33,9 тыс. кв. м (в 5,5 раза). Свыше $80 \%$ теплиц и $57,5 \%$ парников колхозов расположены вблизи Таллина; в зоне сланцевого бас сейна расположено только $12,3 \%$ парников и $1,5 \%$ теплиц.

В 1953 году всего в республике по всем системам было 159,7 тыс. кв. м теплиц и парников, в том числе теплиц (отапливаемых и неотапливаемых) - 64,6 тыс. кв. м, парников - 95,1 тыс. кв. м. Из общей площади теплиц и парников колхозам принадлежит $29,2 \%$, совхозам - $17,7 \%$, Министерству торговли и потребкооперации - 53,1\%. Таким образом, свыше $50 \%$ теплиц и парников принадлежит Министерству торговли и потребкооперации. Ведущая роль в производстве тепличных и парниковых овощей сохранится и в дальнейшем за ними. Основную массу зимней 
и ранневесенней овощной зелени (зеленый лук, редис, салат) должны производить главным образом хозяйства этих ведомств.

Нз общего количества теплиц и парников вблизи Таллина находится теплиц $56,5 \%$ и парников $32,8 \%$, а в зоне сланцевого бассейна - $18,4 \%$ теплиц и 9,9\% парников. Остальные парники и теплицы находятся в дру гих районах республики.

Из этих данных видно, что развитие тепличного хозяйства в зоне сланцевого бассейна отстает в сравнении с Таллинской зоной. Поэтому темпы роста тепличного хозяйства в зоне сланцевого бассейна должны быть относительно выше, чем в зоне Таллина.

В определении перспектив развития теплично-парникового хозяйства колхозов мы исходим из того, чтобы за счет зимних и ранневесенних овощей удовлетворить по крайней мере $3-4 \%$ общей потребности в овощах (5-6 кг на каждого жителя).

Для этого необходимо в ближайшие годы площадь теплиц в колхозах пригородной зоны Таллина довести до 110 тыс. кв. м (т. е. увеличить в сравнении с 1953 годом в 10,7 раза), а в зоне сланцевого бассейна до 55 тыс. кв. м (увеличение в 275 раз), площадь парников в колхозах зоны Таллина довести до 56 тыс. кв. м (рост в 2,9 раза), а в зоне сланцевого бассейна - до 28 тыс. кв. м (увеличение в 6,6 раза). Урожай овощей проектируется 8-9 кг с кв. м. Подсчеты показывают, что такие темпы роста теплично-парникового хозяйства реальны.

Теплицы и парники в колхозах проектируются трех типов на местном топливе и двух типов - на тепловых отходах промышленности.

Соотношение между обогреваемыми и необогреваемыми теплицами и парниками различно в зависимости от вида топлива и размера тепличного хозяйства. По первому типу (на местном топливе) предлагается такое соотношение: обогреваемые теплицы - $20 \%$, необогреваемые $60 \%$, обогреваемые парники - $10 \%$, необогреваемые также $10 \%$. При этих же размерах, но на тепловых отходах промышленности предлагается такое соотношение: обогреваемые теплицы - 50\%, необогреваемые - 20\%, обогреваемые и необогреваемые парники - по 15\% каждый.

Подсчеты показали, что промышленность республики располагает большим количеством тепловых отходов. Используя эти тепловые отходы, можно организовать тепличное хозяйство в значительных размерах. Надо иметь в виду и то обстоятельство, что расходы на топливо в тепличном хозяйстве составляют $40-45 \%$ себестоимости овощей. Таким образом, использование тепловых отходов даст большой экономический эффект. В обогреваемых теплицах необходимо получать по меньшей мере три урожая в год, а в парниках - в среднем два урожая.

В текущем году в республике ведутся крупные работы по строительству теплично-парниковых комбинатов. Такие комбинаты строятся в колхозах «Тулевик» и «Койт», Харьюского района, и др. Уже в текущем году производство овощей будет резко увеличено.

В связи с организацией крутого подъема производства овощей как открытого, так и закрытого грунта с целью обеспечения населения свежими овощами в течение всего года встает ряд крупных производственных и организационно-хозяйственных вопросов, без своевременного разрешения которых невозможно выполнить поставленные задачи. Основные из этих вопросов следующие:

1. Правильное планирование и размещение овощей открытого и закрытого грунта по колхозам и совхозам, а закрытого грунта - и по другим системам, в соответствии с экономическими и природными условиями хозяйства. 
2. Специализация көлхозов и совхозов на определенных видах товарных овощей (3-4 основные товарные культуры в открытом грунте), с тем чтобы можно было осуществить комплексную механизацию их производства и специализировать кадры.

3. Разработка агротехнического комплекса и системы удобрений в соответствии с экономическими и почвенными условиями каждого хозяйства на основе прогрессивных приемов возделывания овощей. Снабжение всех хозяйств нужными семенами овощных культур высоких кондиций и лучших.в данных условиях сортов.

4. В широких масштабах организовать помощь промышленности сельскому хозяйству как по линии наиболее рационального использования тепловых отходов, так и по линии организации промышленного производства строительных деталей теплиц и парников, парниковых рам, труб, резиновых шлангов, стекла, овощеводческого инвентаря, простейших машин и орудий.

5. В целях организации круглогодового обеспечения населения свежими овощами необходимо построить в промышленных центрах овощехранилища для хранения овощей в свежем виде, примерно на $30-40 \%$ реализуемых в зимний период овощей; $10-20 \%$ свежих овощей зимнего потребления следует рекомендовать колхозам хранить на месте, а часть свощей перерабатывать (квашеная капуста, соленые огурцы) для реализации их в первые месяцы следующего года.

Такая организация овощеводства обеспечивает круглогодовое и полное удовлетворение потребностей населения промышленных центров в свежих овощах и во много раз увеличивает доходы колхозов и колхозников от овощеводства.

Важное значение имеет правильная организация производства картофеля. В республике имеются исключительно благоприятные природные условия для выращивания картофеля. Изучение состояния обеспеченности картофелем населения промышленных центров показало, что за счет пригородной сельскохозяйственной зоны потребности населения в картофеле в г. Таллине удовлетворяются на $34 \%$, а в сланцевом бассейне - на $22 \%$. Снабжение населения г. Таллина и в дальнейшем в значительной мере будут обеспечивать колхозы, не входящие в пригородную зону. Население же сланцевого бассейна может быть обеспечено почти полностью за счет пригородной зөны.

Проблема резкого увеличения производства картофеля является одинаково важной для всех колхозов республики, но в пригородной зоне и вблизи крахмалопаточных и спиртовых заводов концентрация картофеля значительно превышает среднюю по республике.

За последние годы удельный вес картофеля в посевных площадях республики непрерывно и быстро возрастает. Так, если в 1945 году он составлял $11,6 \%$, то уже в $1953-13,8 \%$. В буржуазное время в Эстонии удельный вес картофеля был ниже $(9,7 \%)$, а валовой сбор значительно меньше (на 18\%). Посевы картофеля в республике продолжают возрастать. Только в 1954 году площадь, занимаемая картофелем, уве-

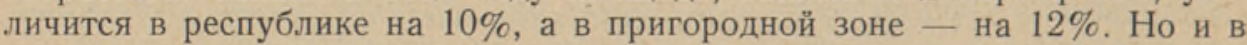
производстве картофеля главное - не увеличение площадей, а резкое дальнейшее повышение урожайности на основе применения комплексной механизации его возделывания, повышения агрокомплекса и улучшения ухода.

Урожайность картофеля в ближайшие 2-3 года необходимо довести до 150 ц г га. Чтобы обеспечить такой урожай, необходимо на каждый гектар картофеля внести 15-20 т органических удобрений (навоз, торф), 
обогащенных фосфорными и калийными удобрениями $(2-3$ ц), и провести одну подкормку внесением $1-1,5$ ц азотных удобрений.

Использование органических удобрений в обогащенном виде дает высокий экономический эффект и позволяет более рационально расходовать ценные органические удобрения (навоз и торф). Этот способ с успехом применяется в ряде колхозов нашей республики. Так, в колхозе «Вамбола», Раплаского района, в 1952 году при внесении на каждый гектар 15 т навоза, обогащенного фосфоритной мукой и калийной солью, был получен урожай 202 ц картофеля с га, при внесении же на 1 га 30 т обыкновенного навоза и раздельно от него тех же количеств минеральных туков - 195 ц. Аналогичные результаты получены в колхозе «Уус Элу», Раплаского района.

Важно отметить, что возделывание картофеля дает колхозам большой экономический эффект и как товарная культура (средний доход 3-4 тыс. руб. с га), и как сочный корм для скота (дает наибольшее количество кормовых единиц с гектара при наименьших затратах). Поэтому увеличение производства картофеля в республике сопровождается крупным ростом доходов колхозов и колхозников. Валовая продукция картофеля в ближайшие $2-3$ года должна возрасти примерно в 2 раза.

Решающее значение в крутом увеличении профзводства картофеля и овощей имеет механизация производства этих культур, внедрение в широкую практику передовых прогрессивных методов. Уже имеющийся опыт передовых колхозов и совхозов республики показывает огромный экономический эффект применения этих приемов. Колхоз «Эха», Кейлаского района, и колхоз «Терас», Харьюского района, при квадратно-гнездовом способе посева овощей получили в два раза больший урожай, чем при обычном посеве. В колхозе «Койдула», Қейлаского района, при квадратногнездовом способе посадки картофеля получили прибавку урожая в среднем 67 ц с га (весь урожай 183 ц с га). В совхозе «Роела» (Раквереский район) при этом способе было получено 307 цартофеля с га, а при обычном - 175 ц. Себестоимость одной тонны картофеля при квадратно-гнездовом способе была в два раза ниже, чем при обычном. В упомянутом выше колхозе «Терас» при квадратно-гнездовом способе посева получен урожай капусты 1189 ц га, а при обычном, рядовом - 450 ц.

При квадратно-гнездовом способе посадки картофеля и овощей значительно снижаются затраты труда в сравнении с обычным методом и резко возрастают денежные доходы с 1 га овощей и картофеля. Квадратно-гнездовой способ посадки картофеля и овощей имеет решающее значение в увеличении их производства.

Важное значение в экономике колхозов республики, особенно колхозов пригородной зоны, имеет развитие плодово-ягодного садоводства, природные условия для которого в республике весьма благоприятны. В 1951 году $85 \%$ колхозов Таллинской зоны и $70 \%$ колхозов зоны сланцевого бассейна совсем не имели общественных садов и только $10 \%$ колхозов в Таллинской зоне и $27,4 \%$ в зоне сланцевого бассейна имели сады площадью до 5 га; свыше 7,5 га садов имели три колхоза в зоне сланцевого бассейна и один колхоз в Таллинской зоне. Задача состоит в том, чтобы во всех колхозах заложить общественные плодово-ягодные насаждения. Общий размер этих насаждений экономически выгодно, возможно и целесообразно было бы иметь в перспективе в размере $2-3 \%$ от пашни, т. е. примерно $20-25$ га в каждом колхозе.

Поскольку при выращивании ягодных насаждений оборачиваемость средств значительно быстрее, чем при плодовых насаждениях, то в первые годы следует разводить преимущественно ягодники. Закладка фруктовых садов должна происходить с таким расчетом, чтобы к 1960 году сады были 
заложены на всей проектируемой площади. Общая площадь садов и ягодников в пригородной зоне в перспективе может составить в Таллинской зоне $2800-3000$, в зоне сланцевого бассейна - 2200-2300 га.

В садах колхозов, расположенньі́х вблизи крупных промышленных центров, бо́льший удельный вес должны иметь ягоды (земляника, малина), перевозка которых на дальнее расстояние затруднительна. В садах более отдаленных от промышленных центров колхозов должны значительно преобладать фруктовые деревья.

Решающее значение в крутом подъеме производства овощей и картофеля, в развитии животноводства и в подъеме всего сельскохозяйственного производства имеют МТС, полное использование техники. Машиннотракторный парк МТС растет исключительно быстро. В 1953 году по сравнению с 1949 годом количество тракторов в республике увеличилось в 4,7 раза. Комбайнов в 1949 году было всего 7, а в 1953 году - 700.

Однако в работе МТС имеются еще серьезные недостатки. Одной из главных причин отставания сельского хозяйства республики является плохое использование техники. Осуществление решений сентябрьского и февральско-мартовского пленумов ЦК КПСС поможет устранить имеющиеся в работе MTC недостатки и резко усилить влияние MTC на развитие общественного хозяйства колхозов.

Главное внимание MTC в пригородной зоне до сих пор было сосредоточено на выполнении полевых и мелиоративных работ. Тракторами выполнялось $80 \%$ пахоты, $70 \%$ культивации, $40-50 \%$ посева зерновых. Объем мелиоративных работ составлял $40 \%$ от всех работ МТС, причем главная часть этих работ $(68 \%)$ падает на уборку камней. Мало еще механизированы животноводческие процессы и работы по производству овощей и картофеля. В 1953 году посадка картофеля была механизирована всего на $10-15 \%$, междурядная обработка - на $2 \%$. Работы в овощеводстве вообе не были механизированы, хотя в ряде колхозов площади, занимаемые овощами, превышали 40 га. Причина низкой механизации производства картофеля и овощей состояла главным образом в отсутствии соот ветствующих машин, недостаточном их приспособлении к почвенным усло виям республики и плохом использовании имеюшихся машин. Так, на пример, в условиях республики (тяжелые почвы с высокой влажностыю осенью, засоренность камнями) мало пригоден комбайн КОК-2. Массовый выпуск северного картофельного комбайна, приспособленного к условиям северо-западной части Союза, даст возможность шире механизировать, уборку картофеля.

Недостаточно механизирована и сеноуборка. В 1953 году механизмами МТС было убрано только $10 \%$ общей площади многолетних трав. Что же касается естественных сенокосов пригородной зоны, то они в массе своей настолько запущены и засорены камнями, что в таком виде почти не пригодны для механизации. Требуются предварительные работы (очистка от камней и кустарников), коренное и поверхностное улучшение, чтобы механизировать уборку сена с естественных сенокосов.

Механизацией животноводства МТC республики занимаются с 1950 года, но сделаны только первые шаги: введено автопоение в $30 \%$ колхозов, в некоторых колхозах механизированы внутрифермский транспорт, подготовка кормов и доение.

После сентябрьского Пленума ЦК КПСС в работе МТС начался крутой подъем. МТС республики следует снабдить машинами для выполнения особенно важных работ, обеспечивающих создание кормовой базы, и для обеспечения резкого повышения урожайности применительно к местным условиям. Встает вопрос о необходимости оснашения МТС механизмами для добычи и внесения торфа для удобрения (бульдозеры и дру- 
гие, транспортные и погрузочные средства). МТС должны располагать для проведения поверхностного улучшения лугов и пастбищ корчевальными боронами и тяжелыми катками. Важное значение в деле повышения урожайности имеет углубление пахотного слоя. $60-70 \%$ площади пашни пригородной зоны требует углубления пахотного слоя. МТС должны располагать плугами устойчивых конструкций с автоматическими камнезащитными приспособлениями. Система машин МТС должна отвечать требованиям сельскохозяйственного производства пригородной зоны.

\section{Специализация и интенсификация колхозного производства}

Крутой подъем сельского хозяйства пригородной зоны осуществится на основе интенсификации и углубления специализации колхозов. В течение ближайших $2-3$ лет в экономике колхозов пригородной зоны возрастет удельный вес овощеводства, молочного животноводства и производства картофеля.

Интенсивность животноводства будет возрастать во всех колхозах зоны. В соответствии с этим значительно изменится структура животноводства. В настоящее время структура общественного животноводства пригородной зоны следующая: крупного рогатого скота - 55,2\%, свиней $-5,8 \%$, птицы $-2,9 \%$, овец $-2,4 \%$ и лошадей $-33,7 \%$. В соответствии с поставленными перед пригородной зоной задачами в ближайшие годы удельный вес крупного рогатого скота поднимется до $60-65 \%$, свиней - до $8 \%$, домашней птицы - до $3,5 \%$, овец - до $2,5 \%$, соответственно удельный вес лошадей снизится до $21 \%$. Наряду с этим будет происходить быстрый подъем продуктивности животноводства и прежде всего продуктивности крупного рогатого скота, что позволит резко уменьшить затраты труда на единицу продукции. Это явится важнейшим фактором экономического укрепления колхозов.

При условии удовлетворительного разрешения кормовой проблемы, при существующих племенных качествах молочного скота можно к 1960 г. повысить средний удой молока на корову в Таллинской зоне до 3500 литров, а в зоне сланцевого бассейна - до 3000 литров.

Плотность крупного рогатого скота на 100 га пашни, лугов и пастбищ можно довести до 25 единиц (в настоящее время в среднем по зоне 14,8).

В структуре крупного рогатого скота удельный вес коров возрастет с $40,8 \%$ в настоящее время до $60-65 \%$ в 1960 году. Число коров на 100 га пашни, лугов и пастбищ составит 15-17. Такой удельный вес коров с указанной выше продуктивностью обеспечит производство молока в Таллинской зоне в количестве $480-500$ ц на 100 га пашни, лугов и пастбищ, а в зоне сланцевого бассейна - $450-480$ ц.

Все это создает новый, более интенсивный тип животноводства, отличный от существующего в настоящее время.

C развитием сельского хозяйства пригородной зоны подлежат переустрфйству и районы производства цельного молока. Все районы, входящие в пригородную сельскохозяйственную зону, должны стать цельномолочными. Это необходимо как с точки зрения увеличения количества молока, идущего по линии государственных заготовок и государственных закупок, так и с точки зрения улучшения состояния молодняка крупного рогатого скота и свиноводства. Сбыт цельного молока следует предусмотреть в размерах $60 \%$ от общей товарной продукции молока.

C целью равномерного снабжения населения молоком необходимо путем соответствующего регулирования отелов уменьшить сезонность в 


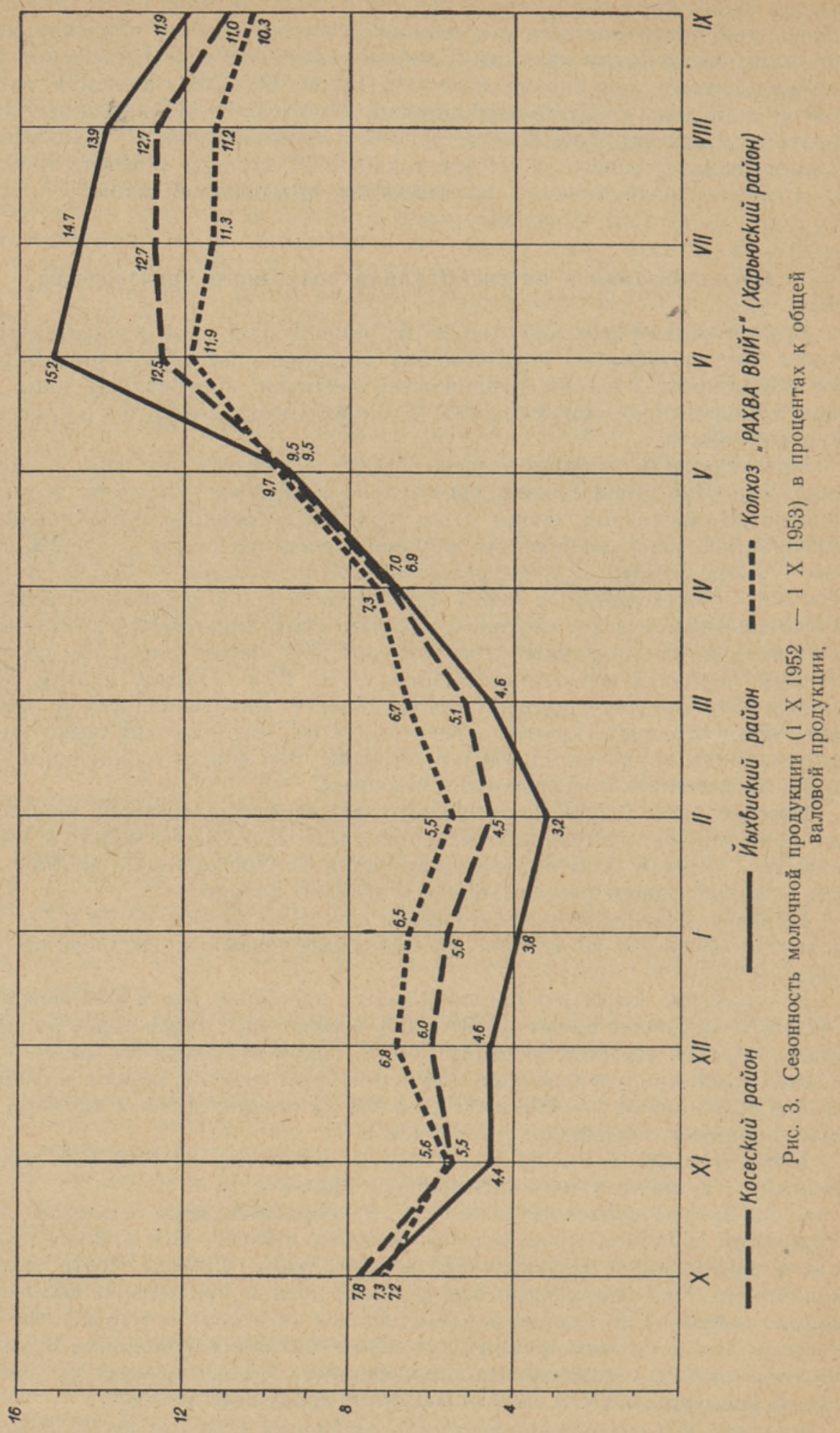


производстве молока. Как видно из рис. 3, наибольший выход молока имеет место в июне, а наименьший - в феврале.

Второй нанболее важной отраслью животноводства является свиноводство, интенсивность которого крайне различна в разных районах пригородной зоны. Так, на 100 га пашни относительно больше свиней имеется в Рапласком (23) и Косеском (21) районах и меньше в Харьюском, Кейласком, Иыхвиском и Кивиылиском районах (16-19).

В течение ближайших лет количество свиней необходимо довести до $30-35$ голов на 100 га пашни, что даст возможность получать $25-30$ ц свинины на каждые 100 га пашни.

Указанные выше мероприятия дают возможность резко повысить товарную продукцию колхозов, денежные доходы колхозов и колхозников.

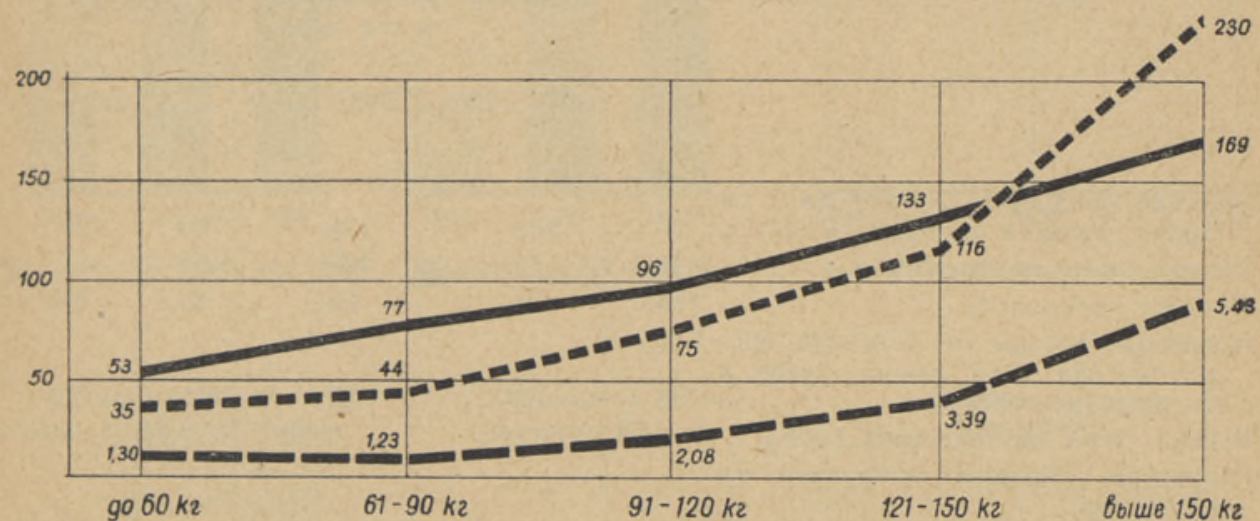

Товарная проgукция молока на оgин

га пашни, лугов и пастбищ.

тобарная продукция малока на 1 га пашни, лугов и пастбищ (среgняя по группам)

- gенежсные gоходы от молочно-тобарной фермы на 1 га пашни, лугоб и пастбищ.

балача gенег на труgоgень 6 рублях

Рис. 4. Зависимость денежных доходов колхозов от товарной продукции молока.

Денежные доходы колхозов и размеры выдачи денег на трудодни колхозникам в значительной степени зависят от товарной продукции молока, поскольку молочное животноводство является ведущим. В более отдаленных колхозах значительную часть денежных доходов дает свиноводство. Установлено, что чем выше товарная продукция молока на 1 га сельскохозяйственных угодий, тем выше денежные доходы колхозов и колхозников, причем денежные доходы на 1 га растут значительно быстрее, чем товарная продукция. Это видно из рис. 4 (данные по колхозам Харьюского района за 1952 год).

Из рис. видно, что в высшей группе товарная продукция молока на 1 га в 3 раза больше, чем в низшей группе (средний выход товарного молока в низшей группе - 53 кг, а в высшей - 169), а денежные доходы от молочной продукции на 1 га пашни, лугов и пастбищ больше почти в 7 раз (в низшей группе 35 руб., а высшей - 230 руб.). Выдача денег на трудодень увеличилась в высшей группе более чем в 4 раза по сравнению с низшей.

Товарная продукция молока и денежные доходы колхозов находятся в прямой зависимости от продуктивности молочного животноводства, но денежные доходы растут быстрее, чем продуктивность. 
С ростом продуктивности изменяется структура товарной продукции, уменьшается удельный вес госпоставок, увеличивается продукция, идущая по линии госзакупок и на колхозный рынок, уменьшается также удельный вес продукции, идущей на хозяйственные нужды. Все это и создает условия для более быстрого роста денежных доходов на 1 га пашни, лугов и пастбищ по отношению к росту продуктивности. Это положение иллюстрируется данными табл. 1 (колхозы Харьюского района, данные за 1952 г.).

Таблица $I$

Зависимость структуры товарной продукции молока и денежных доходов от продуктивности молочного скота

\begin{tabular}{|c|c|c|c|c|c|}
\hline \multirow[b]{2}{*}{ ? } & \multicolumn{5}{|c|}{$\begin{array}{c}\text { Молочная продукция на одну корову } \\
\text { в год (в кг) }\end{array}$} \\
\hline & $\begin{array}{c}\text { до } \\
1500\end{array}$ & $1500-2000$ & $2000-2500$ & $\begin{array}{c}\text { Bb:ше } \\
2500\end{array}$ & $\begin{array}{l}\text { в сред- } \\
\text { нем по } \\
\text { району }\end{array}$ \\
\hline $\begin{array}{c}\text { Валовая продукция молока на } 1 \text { га } \\
\text { пашни, лугов и пастбищ (в кг) }\end{array}$ & 70 & 108 & 126 & 205 & 121 \\
\hline То же, товарная продукция & 48 & 85 & 105 & 165 & 97 \\
\hline Процент товарности & 68,6 & 78,7 & 83,3 & 80,5 & 80,2 \\
\hline $\begin{array}{l}\text { Денежные доходы от молочной про- } \\
\text { дукции (на 1 га пашни, лугов и } \\
\text { пастбищ, в рублях) }\end{array}$ & 46 & 62 & 82 & 261 & 87 \\
\hline Выдано денег на трудодень (руб.) & 0,53 & 1,91 & 2,09 & 7,31 & 2,55 \\
\hline $\begin{array}{l}\text { Структура товарной продукции (в } \\
\text { процентах): }\end{array}$ & & & & & \\
\hline госпоставки & 75,8 & 69,5 & 61,0 & 41,6 & 61,9 \\
\hline госзакуп и кооперация & - & 8,4 & 15,5 & 14,2 & 11,8 \\
\hline колхозный рынок & 4,5 & 8,2 & 13,6 & 43,0 & 15,6 \\
\hline на переработку & 19,0 & 13,2 & 9,8 & 1,1 & 10,1 \\
\hline прочее & 0,7 & 0,7 & 0,1 & 0,1 & 0,5 \\
\hline $\begin{array}{l}\text { Израсходовано на производственные } \\
\text { нужды из валовой продукции мо- } \\
\text { лока }(\%)\end{array}$ & 31,4 & 21,3 & 16,7 & 19,5 & 19,8 \\
\hline
\end{tabular}

Из таблицы видно, что по мере роста продуктивности непрерывно растет и товарная продукция - как относительно, так и абсолютно. Продуктивность в высшей группе возросла менее чем в два раза по сравнению с низшей, выход же товарной продукции на 1 га пашни, лугов и пастбищ увеличился почти в 3,5 раза, а денежные доходы - почти в 6 раз; во много раз увеличилась и выдача денег на трудодни.

Таким образом, повышение интенсивности сельского хозяйства, как основная линия выполнения решений сентябрьского Пленума ЦК КПСС, обеспечивает колхозам и колхозникам быстрый рост денежных доходов, экономическое укрепление колхозов и быстрый рост материального благосостояния колхозников.

Темпы развития общественного хозяйства колхозов пригородной зоны покажем на примерах отдельных конкретных колхозов этой зоны.

В колхозе «Койт» денежные доходы в 1956 году по сравнению с 1953 годом увеличатся более чем в 3 раза (с 782 тыс. руб. до 2570 тыс. руб.). На 1 га пашни, лугов и пастбищ денежные доходы с 890 руб. увеличатся до 2750 руб.; резко возрастет выдача на трудодни. Основой увеличения денежных доходов явится рост товарной продукции: молока на $262 \%$, свинины - на $153 \%$, овощей - на $585 \%$, картофеля - на $320 \%$. 
Количест6о крупного pozamozo ckoma u koров на 100 га пашни, лугов и пастбищ,
Poсm теплично -

nарнuko6oro

хозяйст6а $\quad 6 \mathrm{~kb} . \mathrm{M}$
Pocm посебной площаgu kартофеля u овощей $B$ 2a

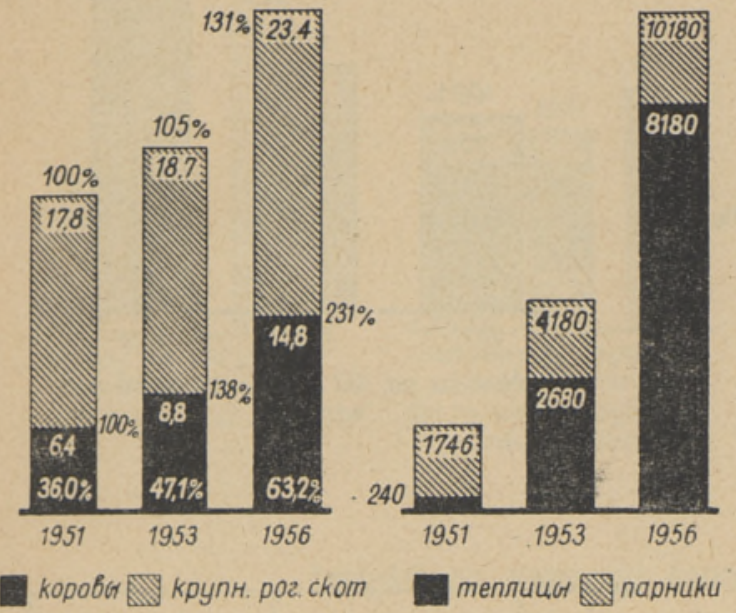

Молока на 100 га пашни, пугов и пастбищ, $6 u$

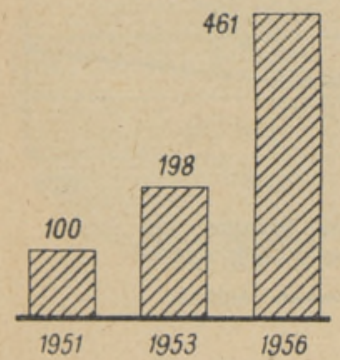

Сбинина на 100 га пашни $b$ ч

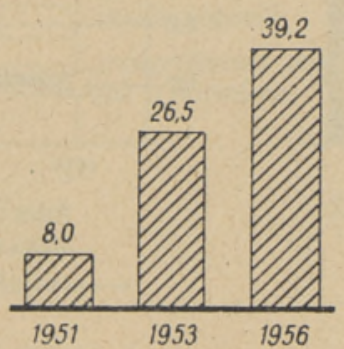

Валовая проgykuия овощей $b$ u
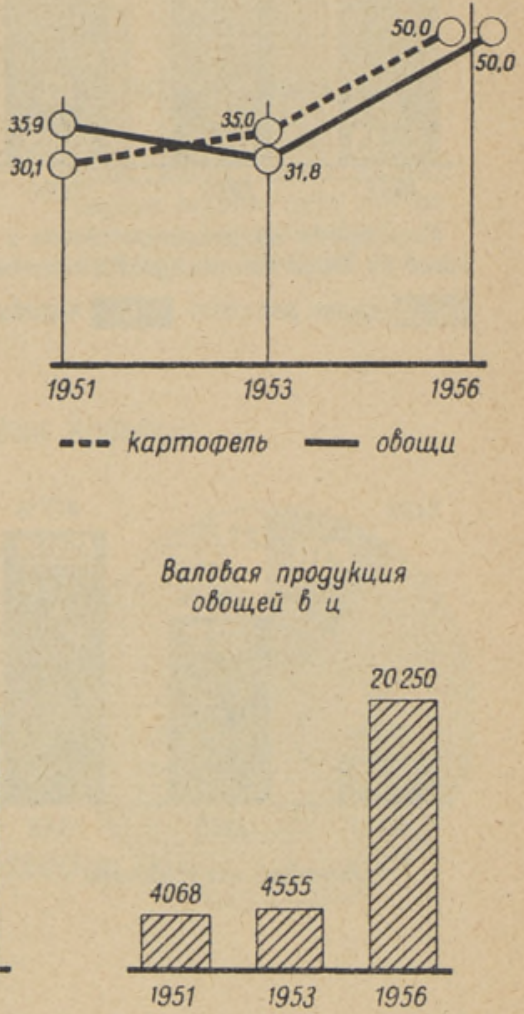

Pocm gенежнах gохоgов на I га пашни, пугов и nacmbum. 'o pyб.

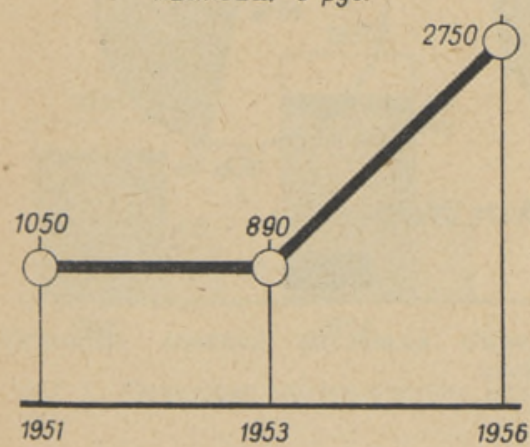

Oплата трудоgня b рублях (бсего)

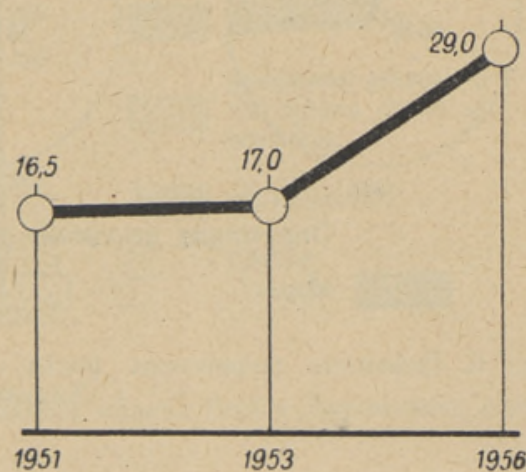

Рис. 5. Основные показатели роста общественного хозяйства и материального благосостояния колхозников колхоза «Койт», Харьюского района. 


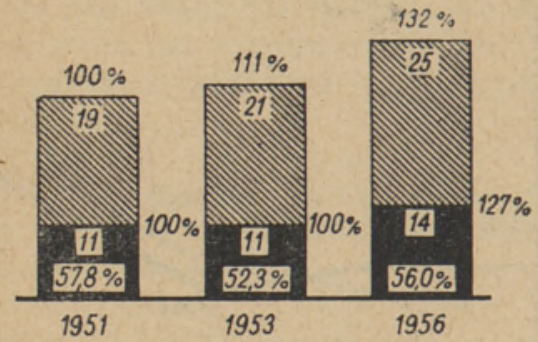

Количестьо kp poramoro ckoma u коро6 на 100 га пашни, луго6 и паст6uиs, крупн. рог.ckom

kopobol

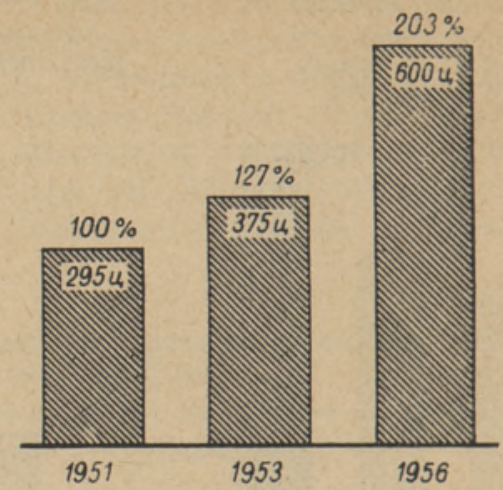

Mолока на 100 га пашни, пугов и пастбищ.
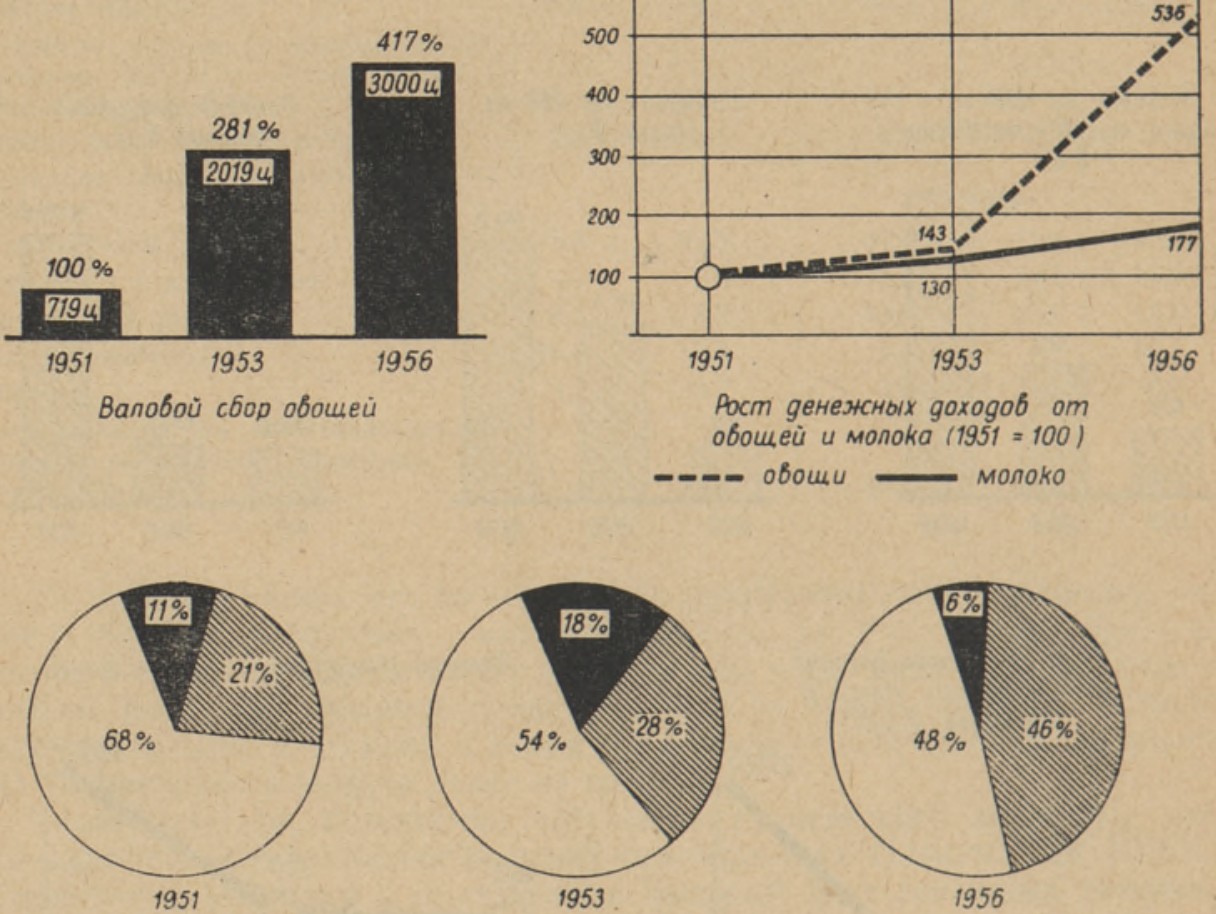

Cmpykmypa gенежнох goxogob (bcero goxogor = 100)
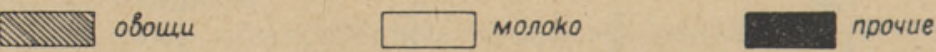

Рис. 6. Основные показатели роста общественного хозяйства колхоза «Виймси», Харьюского района. 
В 1953 2. Бсөго земли 3970 га бл.4. пашни $22 \%$

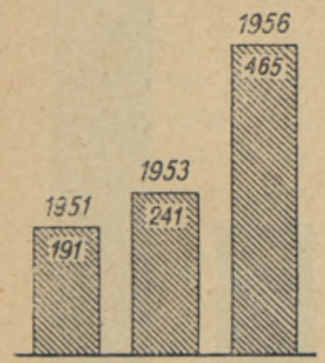

Monoka на 100 га

пашни, пугоб u nacmbuu ( 6 u)

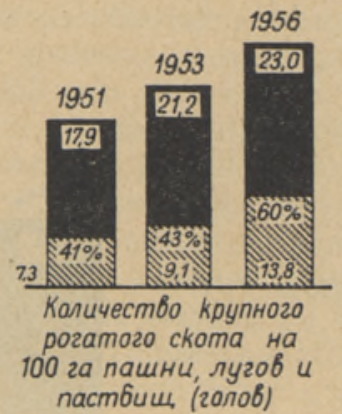

B 19532.6 rpynne kopob gospku Jep. Cou.गp. A. Mukoмягu

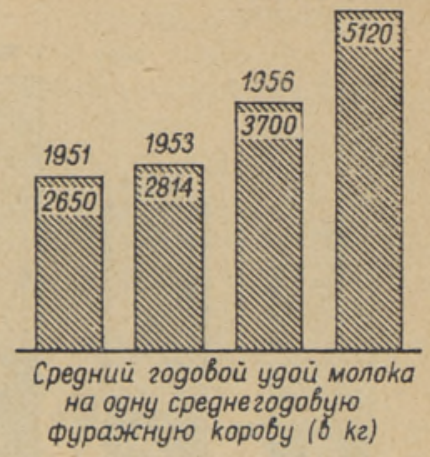

Cтруктура площаяи кормобых культур
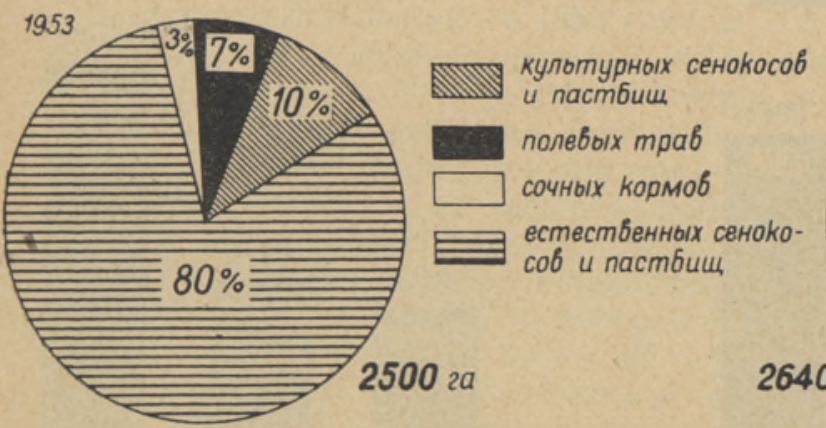

ecmecmбенных сенокоcob u nacmbuu.

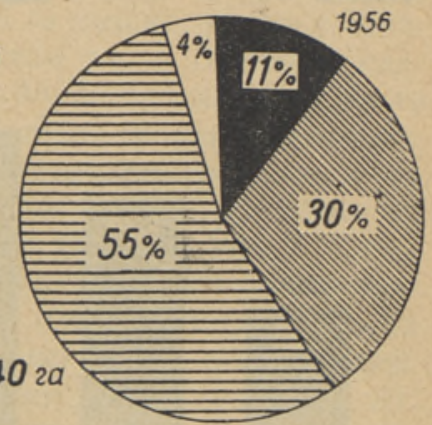

Денежсные gохоg61 колхоза

(b morc. py 6 .)

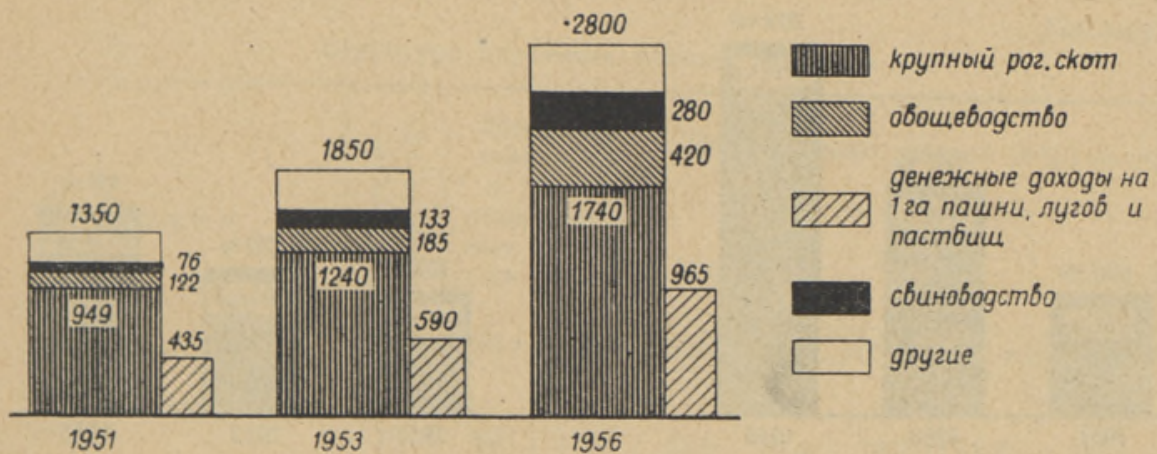

.Рнс. 7. Основные экономические показатели колхоза «Рахва Выйт», Харьюского района. 


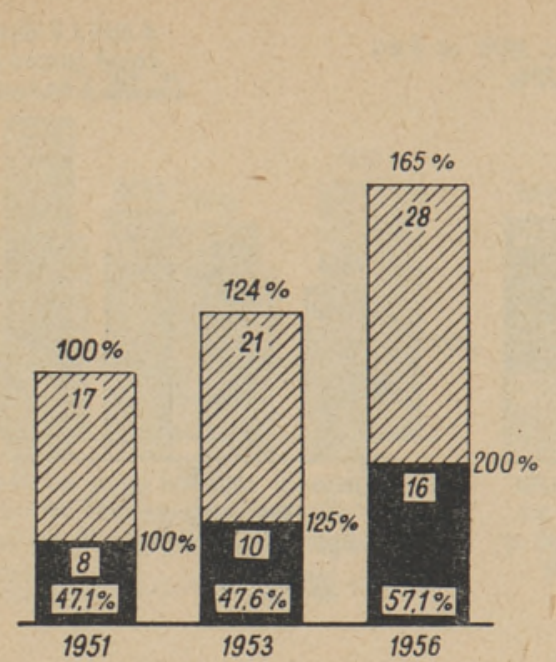

Каличест6о kp poz ckoma u короб на 100 га пашни, лугоб и пастбише EIIII] крупн. poz ckom $k o p o b b l$

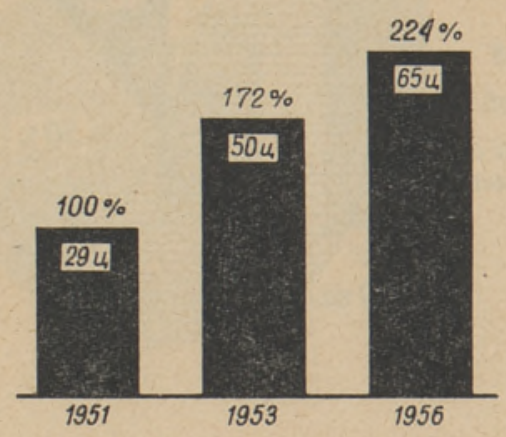

Сбинины на 100 га пашни

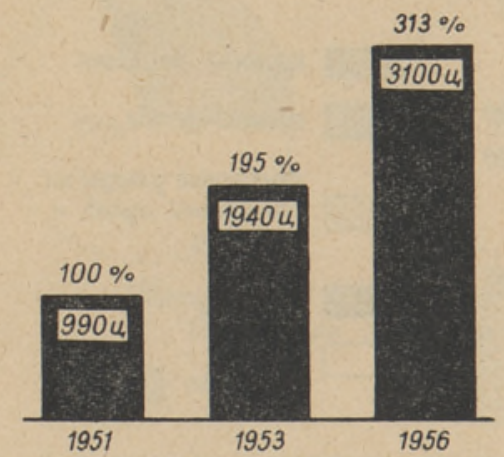

Валовая проgукция овощей
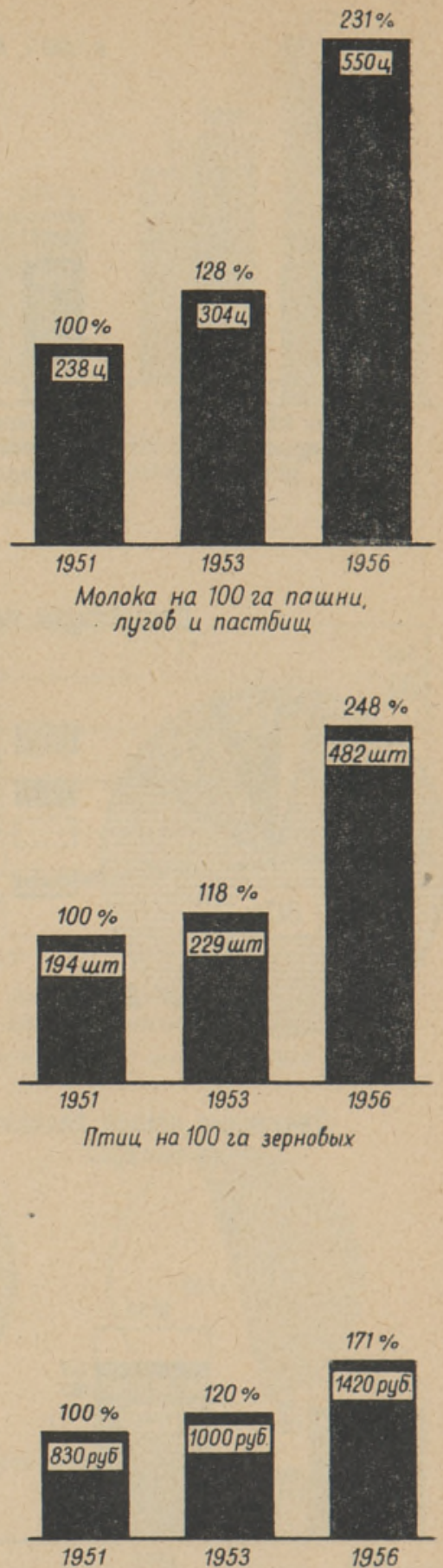

Денежные gоходы на 1га пащни, лугов и пастбищ,

Денежная оплата труgоgня: 1951 - 10,60 py6., 1956 z - 16 руб.

Рис. 8. Основные показатели многоотраслевого развития общественного хозяйства колхоза «Уус Элу», Харьюского района. 
Выход молока на 100 га пашни, лугов и пастб́ищ с 198 щвеличится до 461 ц, свинины на 100 га пашни - с 26,5 до 39,2 ц. В этом колхозе, расположенном вблизи Таллина, особенно быстро возрастет овощеводство и в частности овощеводство закрытого грунта. Товарная продукция овощей с 2943 ц вырастет до 17250 ц, т. е. почти в 6 раз (рис. 5).

Возьмем другой колхоз «Виймси», также расположенный вблизи Таллина. В этом колхозе развито овощеводство и особенно молочное животноводство. Уже в 1953 году этот колхоз получил 375 ц молока на 100 га пашни, лугов и пастбищ (средний удой 3162 л), а в 1956 году запроектировано получить 600 ц молока на 100 га пашни, лугов и пастбищ. Валовой сбор овощей увеличится в 1956 г. по сравнению с 1951 годом в 4,5 раза, денежные доходы от овошей возрастут почти в 5,5 раза (рис. 6).

В колхозе «Рахва Выйт» валовой выход молока в течение ближайших 2-3 лет удвоится, выход молока на 100 га пашни, лугов и пастбищ с 241 ц поднимется до 465 ц, удвоится и товарная продукция овощей. Резко изменится структура кормовой базы, денежные доходы составят почти 3 млн. рублей (рис. 7).

В более отдаленном от промышленного центра (60 км) колхозе «Уус Элу» денежные доходы возрастут с 2,1 млн. рублей почти до 3,3 млн. рублей. В этом колхозе уже в настоящее время высоко развиты все отрасли общественного хозяйства и их дальнейший рост будет сравнительно равномерным: Колхоз уже в 1953 году на 100 га пашни, лугов и пастбищ имел 21 голову крупного рогатого скота, в том числе 10 коров, сдавал товарной свинины 50 ц на 100 га пашни; в больших размерах было развито производство картофеля и овощей открытого грунта. В течение ближайших $2-3$ лет произойдет крупный рост общественного хозяйства и в этом колхозе. Поголовье крупного рогатого скота будет доведено до 23 голов на 100 га пашни, лугов и пастбищ, в том числе 16 коров. Валовая продукция молока на 100 га пашни, лугов и пастбищ с 304 ц в настоящее время поднимется до 550 ц, выход товарной продукции свинины на 100 га пашни с 50 ц возрастет до 60-65 ц, резко увеличится сбор овощей, более чем в два раза возрастет валовая продукция картофеля (рис. 8).

Такой же крутой подъем общественного хозяйства колхозов произойдет и в других колхозах пригородной зоны.

Структуры товарной продукции и денежных доходов колхозов будут различны в зависимости от расстояния колхозов до промышленных цент-

Таблица 2

Структура денежных доходов колхозов

\begin{tabular}{|c|c|c|c|c|c|c|c|c|c|}
\hline \multirow{3}{*}{ Кол $о$ о 3 ы } & \multirow{3}{*}{ 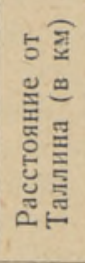 } & \multirow{2}{*}{\multicolumn{2}{|c|}{$\begin{array}{c}\text { Денежные } \\
\text { доходы на } \\
1 \text { га сельско- } \\
\text { хозяйствен- } \\
\text { ных угодий } \\
\text { (в руб.) }\end{array}$}} & \multicolumn{6}{|c|}{ Из денежных доходов (в \%) за } \\
\hline & & & & \multicolumn{2}{|c|}{ овощей } & \multicolumn{2}{|c|}{ молока } & \multicolumn{2}{|c|}{ свинины } \\
\hline & & $1953 \mathrm{r}$. & $1956 \mathrm{r}$. & $1953 \mathrm{r}$. & $1956 \mathrm{r}$. & $1953 \mathrm{r}$. & $1956 \mathrm{r}$. & 1953 г. & $1956 \mathrm{r}$. \\
\hline $\begin{array}{l}\text { «Койт», Харьюского } \\
\text { района }\end{array}$ & 10 & 890 & 2750 & 62,6 & 67,0 & 19,2 & 18,5 & 8,5 & 5,5 \\
\hline $\begin{array}{l}\text { «Рахва Выйт», Харью- } \\
\text { ского района } \\
\text { «Социализми Теэ» }\end{array}$ & 20 & 590 & 965 & 10,5 & 15,0 & 64,0 & 58,0 & 7,2 & 10,0 \\
\hline $\begin{array}{l}\text { «Социализми Теэ», } \\
\text { Косеского района }\end{array}$ & 40 & 308 & 759 & 4,0 & 10,5 & 57,0 & 50,0 & 18,0 & 22,0 \\
\hline района & 60 & 1000 & 1420 & 5,0 & 9,7 & 30,0 & 32,3 & 35,5 & 32,3 \\
\hline
\end{tabular}


ров. Колхозы, расположенные вблизи промышленных центров, будут иметь большой удельный вес товарной продукции овощей, более отдаленные колхозы - свинины. Удельный вес товарной продукции молока во всех колхозах будет высоким, но в отдаленных колхозах он все же будет ниже, чем в средней полосе, поскольку здесь будет высокий удельный вес товарной свинины, и выше, чем в колхозах, расположенных вблизи промышленных центров, поскольку здесь будет высокий удельный вес овощей. Это положение можно проиллюстрировать табл. 2.

Исторические решения сентябрьского Пленума ЦК КПСС явятся основой крутого подъема сельского хозяйства, и на этой основе уже в ближайшие $2-3$ года потребность населения промышленных центров в цельном молоке, свежих овощах, картофеле и других продуктах будет полностью удовлетворена.

Эстонский народ с большим удовлетворением встретил исторические решения сентябрьского и февральско-мартовского пленумов ЦК КПСС и с огромным энтузиазмом взялся за претворение их в жизнь, добиваясь крутого подъема всех отраслей сельского хозяйства, особенно животноводства, производства зерна, овощей и картофеля. 